\title{
Do ICTs Affect Workforce Productivity in Egyptian Industrial Organizations?
}

\author{
Mohamed Elsaadani
}

\begin{abstract}
The present study aims to investigate the influence of Information Communication Technologies-ICTs' dimensions (Information Technology (IT), Management Information System (MIS), Office automation (OA), Intranet and Internet) on workforce productivity for a group of industrial organizations in Alexandria - Egypt. The population of the study included managers and staff members working in different areas related to ICTs in selected industrial organizations at various managerial levels. A descriptive-statistical combined research study was conducted. Simple random sampling was used for the selection of the participating industrial organization. A questionnaire was used as the data collection method. Expert comments were used to check the validity of study instrument, and the reliability of questions was calculated as 79\% using Cronbach's Alpha coefficient. Single variable ttest, Friedman and variance analysis tests were used for the analysis. Study findings revealed that the specified dimensions of ICTs positively affect workforce productivity of industrial organizations in Alexandria - Egypt.
\end{abstract}

Keywords - ICTs, Productivity Management, IT, MIS, OA, Intranet, Internet, Egypt, Industrial Organizations.

\section{RESEARCH OVERVIEW}

$\mathrm{C}$ URRENTLY, business organizations are seeking to find ways to maintain and enhance their competitive positions as a result of the increased global competition [1]. This is why ICTs are adopted by business organizations in order to control complex processes [2]. ICTs in response to competitive pressures can force business organizations to engage in strategic activities [3] and contribute to organizational productivity and overall performance [4], [5].

The progression and advancement of the digital economy and literacy of ICTs has forced itself to become the vital component that changes recent business settings and is used as one of the strategic factors that improve businesses and workforce productivity. Today, Information Communication Technologies (ICTs) are progressing rapidly and studies at an extensive level try to establish a better perception of their effect on productivity.

Paper received May 21, 2014; revised July 8, 2014; accepted July 10 2014. Date of publication July 31, 2014. The associate editor coordinating the review of this manuscript and approving it for publication was Prof. Vlado Delić.

Dr. Mohamed Elsaadani, is an Assistant Professor at the Arab Academy for Science and Technology and Maritime Transport, Alexandria - Egypt (phone: 00201111979966; e-mail: mohamed.elsaadani@gmail.com).
ICTs include the use of technologies in information production, information processing, information retrieval and information distribution. ICTs have brought lots of advantages for their users personally and professionally [6].

ICTs have a considerable potential to promote development and economic growth, as well as to foster innovation and improve productivity. The use of ICTs can bring impressive gains in employment, gender equality, and standards of living [7]. This same idea was shared by [8] as they declared that the improvement of workforce productivity resulted in an enhancement in the economic health and more importantly economic growth, which would result in achieving better life standards.

Reference [9] investigated the business value of ICTs. The author reveals that ICTs result in the existence of what is called a "productivity paradox", no matter whether it is a developed or developing country. [10] declared two main reasons to emphasize the evaluation of the company's productivity instead of using alternative attributes like profitability. The first is the fact that productivity of the organization is obtained directly by changes in the production process. The second is that the impact of ICTs on productivity could be easier than its impact on profitability. This was considered as a major reason for conducting the current research to investigate deeper this issue, as well as to support the objective of current research to study the effect of ICTs on productivity.

Reference [11] investigated the relationship between ICTs acceptance and organizational agility, which is the ability of a business to adapt rapidly in response to changes in its business environment. They tried to find out how the acceptance of ICTs contributes to a firm's ability to be an agile competitor, and they concluded that technology usage had the strongest direct impact on organizational agility.

According to [12], there are five issues needed to be resolved in order to gain increased productivity: 1) Reduce time and effort needed to acquire information resources and to communicate with others; 2) Effectively utilize knowledge work routines (methods, procedures, and technology); 3) Achieve learning curve reductions in effort and minimize relearning time for infrequently employed routines; 4) Maximize motivation through work structure; 5) Maximize both availability of attention and value from its use through work structure.

In recent years, productivity and economic growth have been a major focus for many research studies [13] - [16]. Researchers agreed that workforce productivity and 
economic growth were stimulated by investment in ICTs. In the same context, [17] revealed that workforce productivity could be attributed to three different sources: investment in knowledge and ICTs, improvements of qualification through education and training in science and technology, or a combination of both of them.

Nowadays, there is a need to improve the productivity of people, business organizations and even countries by using different types of ICTs. Since recently, people depend on technologies everywhere in their private and professional lives. Moreover, their lives have been driven by both technology and knowledge as the knowledge work has replaced traditional work and is becoming the most important mode of production [18]. This is also the opinion expressed in [19] as they reveal that ICTs are the most recent revolution in the history of mankind as they have the ability to transform the way people communicate, learn, do business and interact; thus affecting all areas of personal and professional lives at an enormous speed.

The cost of implementing ICTs is not compensated until it is followed by cost reduction and productivity improvement [20]. In [21] it is concluded that achieving high efficiency and effectiveness in business organizations requires investment in ICTs dimensions such as internet [22], office automation systems [23] as well as management information systems [24]. Deploying these systems results in a boost for the economy at large [25] as well as improving workforce productivity [26] - [27].

Organizations are investing in ICTs as they have a positive effect on productivity, thus achieving gains in both efficiency and profitability [28], [21]. Many researchers have studied the important role that ICTs have on business organizations' productivity and competitiveness [29] - [34], but the vast majority of these studies have been done in developed countries (e.g. Japan, the USA, England, Germany, etc). There have been very few studies carried out in developing countries [35].

Recent studies in this regard illustrate that there is a direct relationship between investment in advanced ICTs and applying workforce with high skills. Such studies reveal that there are strong relationships among various actions of the organization and ICTs attributes. They show that the integration of these actions with ICTs has positive impacts on productivity. Among these studies is [36] where the impacts of using ICTs on productivity are studied. [37] investigates the impact of ICTs on the performance of small and medium enterprises. They reveal that the increasing use of ICTs plays important roles in increasing workforce productivity.

In the same context, [38] studies the impact of ICTs on productivity. They find out that the increasing usage of ICTs has significant roles in productivity enhancement. Moreover, [39] declares that the situation of the application of ICTs in business organizations is strong, and ICTs play an important role as one of the strategic factors which can help improve business productivity.

In the same line of research, [40] reveals that those who are dealing with ICTs achieve long-term profitability through the achievement of: productivity improvement, service quality improvement, cost reduction and individuals' satisfaction. These positive results were confirmed as well by [41]. Earlier, [42] declared that the use of IT in business processes resulted in improving productivity. Researchers have found evidences for a positive effect of ICTs on productivity, and they are certain that ICTs have an enormous effect on business organizations productivity [43] - [44].

The study of the effect of ICTs on productivity is an important theoretical basis for how to use ICTs to improve productivity in general.

\section{RESEARCH MEthodology}

This is a descriptive-statistical combined type of research study. The present study aims to investigate the influence of ICTs dimensions (Information technology, Management Information System, Office automation, Intranet and Internet) on workforce productivity for a group of randomly selected industrial organizations in Alexandria - Egypt through surveying the directory of the listed industrial organizations with the Egyptian Ministry of Trade and Industry.

Simple random sampling was used for the selection of the participating industrial organization. The population of the study included managers and staff members working in different areas related to ICTs in the selected industrial organizations at various managerial levels.

The participating organizations reported that they have a number of 371 managers and staff members working in different areas related to ICTs at various levels. A questionnaire was used as the data collection method based on Likert Scale from completely disagree (1) to completely agree (5). 371 questionnaires were distributed, but only 188 were completed and returned, and will be considered as the study sample.

Expert comments were used to check the validity of the study, and the reliability of questions was calculated as 79\% using Cronbach's Alpha coefficient and confirmatory factorial analysis. Single variable t-test, Friedman and variance analysis tests were used for data analysis of the study.

\section{DATA ANALYSIS}

$72 \%$ of the participating study sample was in the age group of 29 to 51 and a majority of them were employees with Bachelor degrees with various specializations. Also $83 \%$ of them had at least 18 years of working experience in the company.

Although all the dimensions of information technology (Information technology, Management Information System, Office automation, Intranet and Internet) played a role in workforce productivity, the results of the Friedman test in table 1 revealed that dimensions priorities are different at a significant level of 0.05 . The IT dimension with a mean of 5.93 has the highest effect on workforce productivity. Internet with a mean of 2.19 has the lowest effect.

The effect of ICTs on workforce productivity is analyzed based on demographic variables (age, educational level, job and working background). Therefore ANOVA test was used as the variance analysis test. The 
result of the effect of ICTs on workforce productivity based on age is shown in table 2. The results of the variance analysis test show that the observed $F$ was not significant at the level of 0.05 . Therefore there were no significant differences between the answers of participating study sample at different ages.

TABle 1: Friedman Test Results For GRAding ICtS DiMENSIONS.

\begin{tabular}{llll}
\hline $\begin{array}{l}\text { Independent } \\
\text { variable }\end{array}$ & Mean & $\begin{array}{l}\text { Sig. } \\
\text { level }\end{array}$ & \\
\hline IT & 5.93 & 0.000 & 287.362 \\
MIS & 3.25 & & \\
Office automation & 4.31 & & \\
Intranet & 3.17 & & \\
Internet & 2.19 & \\
\hline
\end{tabular}

TABLE 2: VARIANCE ANALYSIS TEST RESULTS FOR THE EFFECT OF ICTS ON WORKFORCE PRODUCTIVITY BASED ON AGE.

\begin{tabular}{c|cc}
\hline Sig. level & $\boldsymbol{F}$ & $\begin{array}{c}\text { Independent } \\
\text { variables }\end{array}$ \\
\hline Independent variable & 1.112 & 0.436 \\
IT & 0.415 & 0.914 \\
Office automation & 0.917 & 0.743 \\
Intranet & 1.019 & 0.491 \\
Internet & 0.282 & 0.374 \\
\hline
\end{tabular}

The result of the effect of ICTs on workforce productivity based on the level of education is shown in table 3 . The results of the variance analysis test show that the observed $F$ was significant at the level of 0.05 for both the intranet and the internet dimensions. Therefore there were significant differences between the answers of participating study sample with different levels of education.

TABLE 3: VARIANCE ANALYSIS TEST RESULTS FOR THE EFFECT OF ICTS ON WORKFORCE PRODUCTIVITY BASED ON LEVEL OF EDUCATION.

\begin{tabular}{c|cc}
\hline Sig. level & $\boldsymbol{F}$ & $\begin{array}{c}\text { Independent } \\
\text { variables }\end{array}$ \\
\hline Independent variable & 0.702 & 0.150 \\
IT & 0.206 & 0.750 \\
Office automation & 0.139 & 0.327 \\
Intranet & 3.821 & 0.000 \\
Internet & 6.194 & 0.002 \\
\hline
\end{tabular}

The result of the effect of ICTs on workforce productivity based on their job is shown in table 4 . The results of the variance analysis test show that the observed $F$ was significant at the level of 0.05 for only the internet dimension. Therefore there were significant differences between the answers of participating study sample with regard to their job.

The result of the effect of ICTs on workforce productivity based on their working background is shown in table 5. The results of the variance analysis test show that none of ICTs dimensions were significant at the level of 0.05 . Therefore there were no significant differences between the answers of participating study sample with regard to their working background.

TABLE 4: VARIANCE ANALYSIS TEST RESULTS FOR THE EFFECT OF ICTS ON WORKFORCE PRODUCTIVITY BASED ON JOB.

\begin{tabular}{c|cc}
\hline Sig. level & $\boldsymbol{F}$ & $\begin{array}{c}\text { Independent } \\
\text { variables }\end{array}$ \\
\hline Independent variable & 0.671 & 0.700 \\
IT & 0.190 & 0.207 \\
Office automation & 0.050 & 0.891 \\
Intranet & 1.005 & 0.231 \\
Internet & 3.491 & 0.002 \\
\hline
\end{tabular}

TABLE 5: VARIANCE ANALYSIS TEST RESULTS FOR THE EFFECT OF ICTS ON WORKFORCE PRODUCTIVITY BASED ON WORKING BACKGROUND.

\begin{tabular}{c|cc}
\hline Sig. level & $\boldsymbol{F}$ & $\begin{array}{c}\text { Independent } \\
\text { variables }\end{array}$ \\
\hline Independent variable & 0.366 & 0.821 \\
IT & 0.501 & 0.920 \\
Office automation & 2.007 & 0.371 \\
Intranet & 1.001 & 0.207 \\
Internet & 1.110 & 0.072 \\
\hline
\end{tabular}

The present study aims to investigate the influence of ICTs dimensions on workforce productivity for a group of randomly selected industrial organizations in Alexandria Egypt. Table 6 shows the single variable t-test that was used in order to analyze instrument dimensions. The observed $t$ is significant at the level of 0.05 for all the included ICTs dimensions; thus it can be concluded that each of ICTs dimensions positively affect workforce productivity.

\section{CONCLUSION}

In order to improve workforce productivity, business organizations are required to increasingly adopt ICTs. The results of the conducted statistical analysis have led us to a conclusion that the application of various ICTs dimensions can effectively increase workforce productivity, which is in accordance with the research presented in [4]-[6], [10], [20], [28] - [34], [36], [38] - [47]. 
It is highly recommended for the industrial organizations to invest in adopting various dimensions of ICTs in order to positively enhance and develop workforce productivity.

TABLE 6: SINGLE VARIABLE T-TEST RESULTS FOR INSTRUMENT QUESTIONS.

\begin{tabular}{c|ccc}
\hline $\begin{array}{c}\text { Independent } \\
\text { variables }\end{array}$ & Mean & $\boldsymbol{T}$ & Sig. level \\
\hline IT & 5.0498 & 22.194 & 0.000 \\
MIS & 4.2522 & 15.478 & 0.001 \\
Office automation & 3.4811 & 21.566 & 0.000 \\
Intranet & 3.1077 & 7.007 & 0.000 \\
Internet & 3.2821 & 6.331 & 0.000 \\
\hline
\end{tabular}

\section{REFERENCES}

[1] Ellram, L. et al. (1999). Retail logistics. International Journal of Physical Distribution \& Logistics Management, 29(7/8), pp. 477 494.

[2] Brown, J. et al. (2005). Supply chain management and the evolution of the 'Big Middle'. Journal of Retailing, 81(2), pp. 97-105.

[3] Bridges, E. \& Freytag, P. (2009). When do firms invest in offensive and/or defensive marketing? Journal of Business Research, 62(7), pp. 745-749.

[4] Melville, N. et al. (2004). Information technology and organizational performance: an integrative model of IT business value. MIS Quarterly, 28(2), pp. 283-322.

[5] Tsai, W. \& Tang, L. (2012). A model of the adoption of radio frequency identification technology: the case of logistics service firms. Journal of Engineering and Technology Management, 29(1), pp. 131-151.

[6] Phuong, T. (2008). Internet use, Customer Relationships and loyalty in the Vietnamese travel industry. Asia Pacific Journal of Marketing and Logistics, 20, pp. 190-210.

[7] UNCTAD, (2004). E-Commerce and Development Report [Online]. United Nations Conference on Trade and Development. Retrieved December 17, 2013, from http://unctad.org/en/Docs/ ecdr2004overview en.pdf.

[8] Battisti, G. \& Iona, A. (2009). The UK productivity gap in the service sector: do management practices matter? International Journal of Productivity and Performance Management, 58(8), pp. 727-747.

[9] Lin, W. (2009). The business value of information technology as measured by technical efficiency: Evidence from country-level data. Decision Support Systems, 46(4), pp. 865-874.

[10] Fuentelsaz, L. et al. (2009). The effects of new technologies on productivity: An intra-firm diffusion-based assessment. Research Policy, 38(7), pp. 1172-1180.

[11] Zain, M. et al. (2005). The relationship between information technology acceptance and organizational agility in Malaysia. Information \& Management, 42(6), pp. 829-839.

[12] Davis, B. (2001). An Emerging Issue: Knowledge Worker Productivity and Information Technology. Information Science Conference, Krokow - Poland.

[13] Pilat, D. \& Schreyer P. (2004). The OECD Productivity Database: An Overview. International Productivity Monito, OECD, 8, Spring.

[14] Boswoth, B. \& Triplett, J. (2000). Productivity in the Services Sector. American Economic Association (AEA), January 7-9, Boston - Mass.

[15] Jorgenson, D. \& Stiroh, K. (2000). Raising the speed limit: US Economic growth in the Information Age. Brookings Papers on Economic Activity, 1, pp. 125-211.

[16] Oliner, S. \& Sichel, D. (2000). The Resurgence of Growth in the Late 1990's: Is Information Technology the Story? Journal of Economic Perspectives, 14(4), pp. 3-22

[17] Mas, M. \& Quesada, J. (2005). ICT and Economic Growth: A Quantification of Productivity Growth in Spain 1985-2002. OECD Statistics Working Papers, 4, OECD Publishing. Doi: $10.1787 / 527376367825$.

[18] Laudon, K. \& Laudon, J. (2005). Management Information System: Managing the Digital Firm. 9th ed. Prentice Hall, USA.
[19] Pavic, S. et al. (2007). Could e-business create a competitive advantage in UK SMEs? Benchmarking: An International Journal, 14(3), pp. 320-351.

[20] Gichoya, D. (2005). Factors Affecting the Successful Implementation of ICT Projects in Government. The Electronic Journal of e-Government, 3(4), pp 175-184.

[21] Brady, M. et al. (2008). Researching the role of information communication technology (ICT) in contemporary marketing practices. Journal of Business \& Industrial Marketing, 23(2), pp. $108-114$

[22] Deeter-Schmelz, D. \& Kennedy, K. (2004). Buyer-seller relationships and information sources in an e-commerce world. Journal of Business \& Industrial Marketing, 19(3), pp. 188-196.

[23] Geiger, S. \& Turley, D. (2005). Personal selling as knowledgebased activity: communities of practice in the sales force. Irish Journal of Management, 26(1), pp. 61-71.

[24] Li, E. (1995). Marketing information systems in US companies: a longitudinal analysis. Information and Management, 28(1), pp. 1331.

[25] Martin, L. \& Matlay, H. (2001). Blanket approaches to promoting ICT in small firms: some lessons from the DTI ladder adoption model in the UK. Internet Research: Electronic Networking Applications and Policy, 11(5), pp. 399-410.

[26] Grandon, E. \& Pearson, J. (2004). Electronic commerce adoption: an empirical study of small and medium US business. Information and Management, 42(1), pp. 197-216.

[27] Srensena, C. et al., (2010). Conceptual model of a future farm management information system. Computers and Electronics in Agriculture, 72, pp. 37-47.

[28] Zafiropoulos, C. et al. (2006). Research in Brief: the internet practices analysis from Greece. International Journal of Contemporary Hospitality Management, 18(2), pp. 156-163.

[29] Abereijo, I. et al. (2009). Technological innovation sources and institutional supports for manufacturing small and medium enterprises in Nigeria. Journal of Technology Management and Innovation, 4(2), pp. 82-89.

[30] Flor, M. \& Oltra, M. (2005). The influence of firms' technological capabilities on export performance in supplier-dominated industries: the case of ceramic tiles firms. R\&D Management, 35(3), pp. 333-347.

[31] Jones, M. \& Crack, D. (2001). High-technology firms' perceptions of their international competitiveness. Strategic Change, 10(3), pp. 129-138.

[32] Lo'pez, J. \& Garci'a, R. (2005). Technology and export behavior: a resource-based view approach. International Business Review, 14(5), pp. 539-557.

[33] Powell, T. \& Dent-Micallef, A. (1997). Information technology as competitive advantage: the role of human, business, and technology resources. Strategic Management Journal, 18(5), pp. 375-405.

[34] Zeng, S. et al. (2008). Competitive priorities of manufacturing firms for internationalization: an empirical research. Measuring Business Excellence, 12(3), pp. 44-55.

[35] Jesús C. et al. (2012). Effect of ITC on the international competitiveness of firms. Management Decision, 50(6), pp. 10451061.

[36] Black, S. \& Lynch, L. (2004). What's driving the new economy? The benefits of workplace innovation. The Economic Journal, 114(493), pp. 97-116.

[37] Lee, Y. et al. (2011). The impact of service R\&D on the performance of Korean information communication technology small and medium enterprises. Journal of Engineering and Technology Management, 28(1-2), pp. 77-92.

[38] Boothby, D. \& Dufour, A. (2010). Technology adoption, training and productivity performance. Jianmin Tang Research Policy, 39, pp. 650-661.

[39] Yang, K. et al. (2007). Adoption of information and communication technology. Industrial Management \& Data Systems, 107(9), pp. 1257-1275.

[40] Law, R. \& Jogaratnam, G. (2005). A study of hotel information technology applications. International Journal of Contemporary Hospitality Management, 17(2/3), pp. 170-180.

[41] Karadag, E. \& Dumanoglu, S. (2009). The productivity and competency of information technology in upscale hotels - the perception of hotel managers in Turkey. International Journal of Contemporary Hospitality Management, 21(4), pp. 479-490.

[42] Drucker, P. (1999). Knowledge Worker Productivity: the Biggest Challenge. California Management Review, 41(2), pp. 79-85.

[43] Jayaram, J. et al. (2000). The effects of information system infrastructure and process improvements on supply-chain time 
performance. International Journal of Physical Distribution and Logistics Management, 30(3/4), pp. 314-30.

[44] Olson, J. \& Boyer, K. (2003). Factors influencing the utilization of internet purchasing in small organizations. Journal of Operations Management, 21(2), pp. 225-245.

[45] Timmer, P. \& Arky, B. (2005). Does information and communication technology drive EU-US productivity growth differentials? Oxford Economic Papers, 57, pp. 693-716.
[46] Iwe, J. (2005). Enhancing women's productivity in the library and information sector in Nigeria. The Electronic Library, 23(3), pp. 319-332.

[47] Koning, J. \& Gelderblom, A. (2006). ICT and older workers: no unwrinkled relationship. International Journal of Manpower, 27(5), pp. 467-490. 